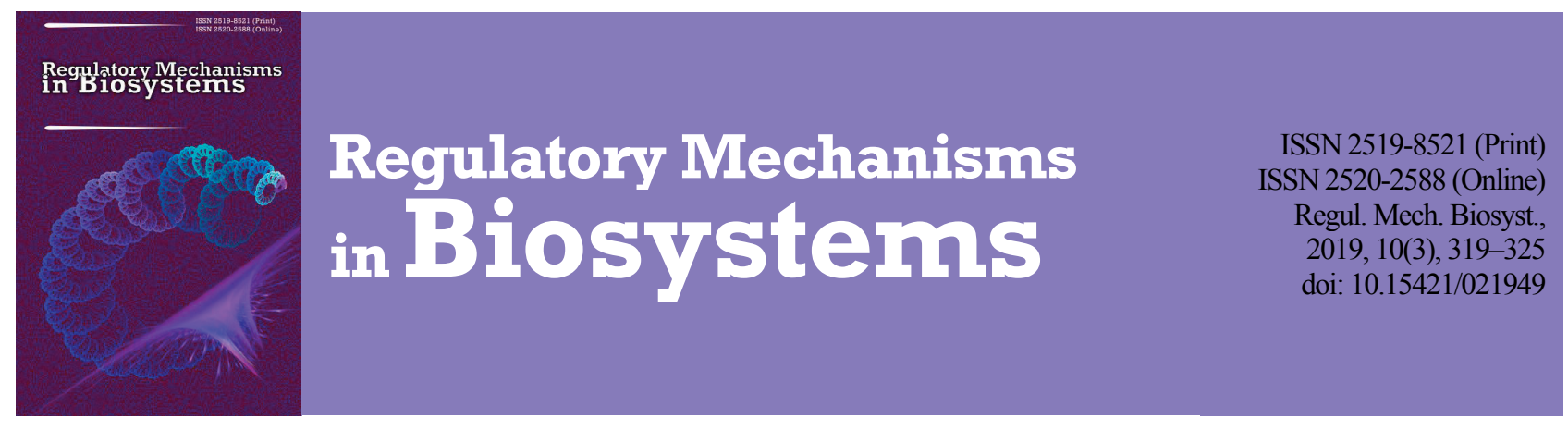

\title{
Oxidatively modified proteins in kidneys of rats fed with glyphosate-resistant genetically modified soybean and the herbicide Roundup
}

\author{
I. V. Chorna*, G. B. Dronik**, T. O. Lukashiv***, V. D. Yuzkova**** \\ *National Technical University "Kharkiv Polytechnic Institute", Kharkiv, Ukraine \\ **Bukovinian State Agricultural Research Station NAAS, Chernivtsi, Ukraine \\ ***Yuriy Fedkovych Chernivtsi National University, Chernivtsi, Ukraine \\ ****Chernivtsi in-Service Teacher Training Institute, Chernivtsi, Ukraine
}

Article info

Received 16.07.2019

Received in revised form 20.08.2019

Accepted 22.08.2019

National Technical University of Kharkiv Polytechnic Institute, Kyrpychova st., 2 Kharkiv, 61002, Ukraine. Tel.: +38-057-707-66-00.

E-mail:chorna8@ukr.net

Bukovyna State Agricultural Research Station NAAS, Bogdan Kryzhanivskyi st., 21 Chernivtsi, 58026, Ukraine. Tel.: +38-037-252-92-20.

Yuriy Fedkovych Chernivtsi National University, Kotsyubynskoho st., 2 ,

Chernivtsi, 58012, Ukraine. Tel.: $+38-037-258-48-11$.

Institute of Postgraduate Teacher Education of Chernivtsi Region, Ivan Franko st., 20, Chernivtsi, 58010, Ukraine.

Tel.: +38-037-252-73-36 E-mail:uzkova@@ukr.net

\section{Introduction}

Traditional selection methods are currently being replaced by the technology of genetic engineering, consisting in modifying of an organism's genetic material (genetic modification). A fragment of one organism's DNA is transferred to another organism's genome. Due to such changes, genetically modified organisms acquire the desired characteristics (drought tolerance, frost resistance, herbicide resistance, etc.). Transgenic plants are widely used in agriculture, medicine, the food industry and animal husbandry (Woodmaska et al., 2007; Zagrebelny et al., 2007; Saliha et al., 2010; James, 2013).

Soybean is one of the most popular crops in the world because it contains up to $42 \%$ protein. With regard to transgenic crops, Roundup Ready soybean which is resistant to the herbicide Roundup (the trademark of a glyphosate herbicide) is the most common. A gene of the Agrobacterium tumefaciens bacteria was introduced in the soybean genome to make it resistant to this herbicide. The genetically modified active oxygen species.
Chorna, I. V., Dronik, G. B., Lukashiv, T. O., \& Yuzkova, V. D. (2019). Oxidatively modified proteins in kidneys of rats fed with glyphosate-resistant geneti-cally modified soybean and the herbicide Roundup. Regulatory Mechanisms in Biosystems, 10(3),

Genetic technologies have become a tool for achieving the desired properties of plant crops instead of traditional breeding in recent decades. They consist in artificial editing of a plant genome (genetic modification) by inserting the genes encoding desired fea$38-42 \%$ of proteins in its seeds, and its most common type is GTS 40-3-2 (Monsanto Canada Inc.) line of transgenic soybean. cultivated with this herbicide). Therefore, the study of individual and combined effects of both factors on the free radical oxidation processes in biomolecules is very relevant. Experimental research was performed on 4-month Wistar rats to study the long-term effects of feeding with genetically modified soybean and herbicide "Roundup", both separately and together, on the rat kidneys. (IV group) and receiving the herbicide with drinkable water (V group), there was an increase in the level of carbonyl derivatives in the rat kidney homogenates in the first (F0) and in subsequent generations (F1, F2) of rats. The research results showed that the highest level of carbonyl derivatives was noted in the kidneys of the third generation of rats. Along with the increase in oxidatively modIV and V groups, the lowest level was observed in the third generation. The use of the same transgenic soybean variety not treated withe content of sulfhydryl groups compared to control group rats. Thus, the obtained experimental data indicate that both feeding with the genetically modified soybean the kidneys of rats of all three generations and imbalance of the oxidant-antioxidant system, most notably in the third generation of accumulated in the seeds of transgenic soybean and also it may increase the oxidative modification of proteins in the rat kidneys. Hence, it is necessary to carry out a detailed study of the effects of these factors on histochemical changes in the kidney and liver

Keywords: free radical oxidation of biopolymers; the content of carbonyl derivatives; enzymatic activity; SH-groups; protease;

soybean synthesizes the glyphosate-insensitive bacterial EPSPS replacing the herbicide-inhibited enzyme in the plant, which is why, when a field is treated with the herbicide Roundup, the soybeans continue to grow, whereas weeds die (Kulik et al., 2013, 2015; Zagrebelny et al., 2014).

Glyphosate belongs to low-toxic herbicides, its oral lethal dose $\mathrm{LD}_{50 \text { (rat) }}-5600 \mathrm{mg} / \mathrm{kg}$ was confirmed in experiments on rats (Vecchio et al., 2003; Natarajan, 2007). The herbicide Roundup producers claim that the herbicide is not included in the transgenic plant's metabolism and is rapidly released without harming it. This raises the question of whether the herbicide can remain inactive in the plant tissues, and how it can affect animals and humans consuming the genetically modified soybean. The study of the genetically modified soybean Roundup Ready and the herbicide Roundup showed that the transgenic soybean can accumulate the herbicide, resulting in cell damage due to its biotransformation by the liver cytochrome $\mathrm{P}_{450}$-dependent system in potentially toxic metabolites (Bohn et al., 2014) and active forms of oxygen generation (Richard et al., 2005). 
The investigation of the effects of heavy metals salts and glyphosate (the herbicide Roundup) showed inhibition of the antioxidant system due to decrease in the content of reduced glutathione, and the inhibition of the glutathione system enzymes activity in both serum and liver homogenates, hence indicating the negative effect of the herbicide Roundup (Dmukhalska \& Honskyi, 2016; Lieshchova et al., 2018; Bilan et al., 2019).

Recent studies conducted by American scientists during 2016 and early 2017 have shown that glyphosate can be accumulated both in plants and their seeds, and it cannot be removed by baking or cooking. On February 17, 2016, the FDA announced the determination of glyphosate in food products (Mesnage et al., 2017). Other studies have shown that Roundup causes cellular oxidation damage, an increase in the morbidity of anatomical pathologies, as well as changes in biochemical parameters of urine and blood, indicating a functional deficiency of the liver and kidneys (Myers et al., 2016).

One of the mechanisms of a damaging action can be active generation of oxygen species and initiation of free radical processes. The active species of oxygen interact with different components of the cell: lipids, resulting in their peroxide oxidation; DNA leading to the molecule break-up and causing point mutations, and proteins resulting in a different modifying effect. Especially sensitive to active oxygen species are the SH- and $\mathrm{NH}_{2}$-groups of proteins. As a result of oxidation, $\mathrm{NH}_{2}-$ groups are converted into carbonyl derivatives. As a consequence of the action of active oxygen species on proteins and enzymes, several amino acid functional groups are modified and it leads to the formation of covalent cross-links, the molecule break-up and the loss of its functional activity (Marchenko et al., 2012; Ketsa et al., 2016). Covalent crosslinks can be formed both between protein molecules consisting of an oligomer and between separated oligomers, and inactivation of oligomeric enzymes is accompanied by a decrease in the content of SHgroups in the protein molecule (Manishchenko, 2010).

The modified protein becomes sensitive to proteolysis, so studying the proteases activity in kidney cells is also appropriate. It is known that the reduction of oxidized proteins is practically non-existent, and they become the object for the action of specific neutral and alkaline proteases. Since kidneys are one of the main organs for elimination of waste products and toxins from the body through blood filtration, studies of the oxidative modification of proteins in kidney cells can serve as one of the main criteria of the toxic effects of various substances on human and animal organisms.

The purpose of our research was to evaluate the intensity of proteins oxidative modification processes in the rat kidney homogenates, the content of sulfhydryl groups and the activity of proteolytic enzymes when the herbicide Roundup and transgenic soybean treated with this herbicide were used for feeding rats.

\section{Material and methods}

The study complies with the standards for the use of laboratory animals according to the European Convention for the Protection of Vertebrate Animals Used for Experimental and Other Scientific Purposes (Strasbourg, 1986; Kyiv, 2001). Putting the animals to death was performed according to the requirements of the Law of Ukraine No. 3447 IV 21.02.2006 "On the protection of animals from abuse". The protocol of the studies was agreed with the local ethics committee of National Technical University "Kharkiv Polytechnic Institute".

The experiments were carried out on Wistar rats weighing 190 $210 \mathrm{~g}$, which were kept on a standard vivarium diet. The rats were divided into five groups (12 rats in each group): I group - rats kept on a standard vivarium diet (intact rats); II group - in the rat diet up to $26 \%$ of the nutritional value of the standard diet was replaced by traditional soybean; III group - rats were fed with genetically modified soybean not treated with the herbicide Roundup (up to $26 \%$ of the nutritional value of the standard diet); IV group - rats were fed with genetically modified soybean ( $26 \%$ of the nutritional value of the standard diet) treated with the herbicide Roundup; $\mathrm{V}$ group received herbicide Roundup with drinkable water $(0.003 \mu \mathrm{g} / \mathrm{kg}$ of animal weight, which is the maximum permissible concentration within the requirements of the European Union).
The experiment used the Chernivtsi-9 soybean (a domestic variety of soybean provided by the Bukovinian State Agricultural Research Station of NAAS) and the transgenic soybean of the GTS 40-3-2 line ("Monsanto Canada Inc."), resistant to the action of the herbicide Roundup. The soybean samples of both varieties (Chernivtsi-9 and GTS 403-2) (protocol No. 1691-N) were tested for genetic modification by the Ukrainian Laboratory of Quality and Safety of AIC products (DSTU ISO 21569:2008 and DSTU ISO 2157:2005). Target sequences of 35S cauliflower mosaic virus (CaMV) promoter and NOS terminator (T-NOS) from Agrobacterium tumefaciens were identified in the sample No 2. As stated in the laboratory results, the soybean of the Chernivtsi-9 variety according to the chemical composition (humidity, mass fraction of proteins, fats, elements) is equivalent to the genetically modified glyphosate resistant soybean GTS 40-3-2 variety. The differences detected by separate indicator are within the limits of biological norm. To neutralize anti-nutrients and reduce urease activity, the soybeans were heat treated for 2 hours at $140^{\circ} \mathrm{C}$ before being added to the feed.

Then 6 females and 6 males were selected for each experimental group (the first generation, $\mathrm{F}_{0}$ ). After being fed the appropriate diets for 42 days, females of each group were mated to males of the same experimental group. Then the rats continued to be fed the same diets, and the next generation rats stayed on the same diets. One and a half months later, $F_{1}$-generation rats were separated from their mothers. 12 rats $(6 \mathrm{fe}-$ males and 6 males) were selected from each group and they continued to be fed the appropriate diets. In the same way $\mathrm{F}_{2}$-generation rats were bred. They were fed as $\mathrm{F}_{0}$ and $\mathrm{F}_{1}$-generation rats. At the age of 12 months, the rats of each generation were decapitated and their kidneys were taken for biochemical examination.

The determination of the content of protein carbonyl derivatives in the kidney homogenates was performed using dinitrophenylhydrazine (Dubinina et al., 1995), the optical density was recorded in a spectrophotometer at $370 \mathrm{~nm}$ (neutral ketone derivatives), the content of sulfhydryl groups (SH-groups) was determined by the methodology (Murphy et al., 1989). The determination of proteolytic activity (alkaline and neutral proteases) was carried out using the modified Anson method (Anne et al., 2001). A unit of proteolytic activity was defined as the amount of enzyme that converts hemoglobin in unprecipitated by trichloroacetic acid condition for $1 \mathrm{~min}$. at a temperature of $30{ }^{\circ} \mathrm{C}$ in the amount corresponding to $1 \mu \mathrm{mol}$ of tyrosine. Statistical processing of the data was performed according to nonparametric Kruskal-Wallis test, as an alternative to one-dimensional (intergroup) analysis of variance. The Conover-Iman test (Conover \& Iman, 1979; Conover, 1999) was used to compare stochastic domination and to determine the results of various pairwise comparisons after the Kruskal-Wallis test for stochastic domination among $\mathrm{n}$ groups (Kruskal \& Wallis, 1952). Statistical data processing was performed using the RStudio (RStudio Team, free license, RStudio: Integrated Development for R. RStudio, Inc., Boston, MA URL, 2016) software package. The differences at the significance level $\mathrm{P}<0.05$ were considered significant.

\section{Results}

The study showed that the feeding with genetically modified soybean leads to a slight increase in the level of oxidative modification of proteins in the kidney homogenates of the first generation rats (Fig. 1). The concentration of oxidatively modified proteins was increased more in the kidneys of rats of the next two generations. The level of carbonyl derivatives in the kidneys was significantly increased in the rats fed with genetically modified soybean treated with the Roundup herbicide and the rats receiving the herbicide with drinkable water at the concentration of $0.003 \mu \mathrm{g} / \mathrm{kg}$ of animal weight.

Considering the above-mentioned data, we have analyzed the level of carbonyl derivatives in the kidney homogenates for each of the three rat generations separately. The statistical difference of medians was established for the experimental groups using the Conover-Iman test. The test showed statistically significant median difference for almost all experimental groups. The greatest difference was found for the rats fed with the transgenic soybean treated with the herbicide and the rats receiving the herbicide with drinkable water. 


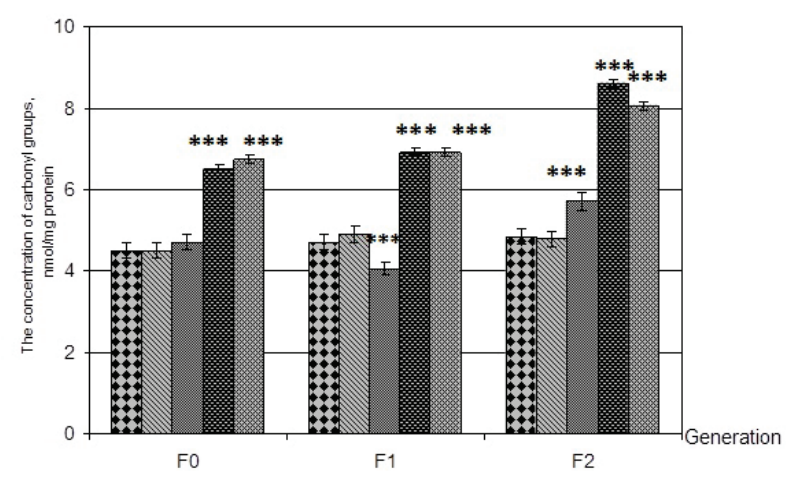

Fig. 1. The level of protein carbonylation in the kidney homogenates of three generations of rats fed with traditional, transgenic soybean not treated with herbicide, transgenic soybean treated with the herbicide and the Roundup herbicide (at a dose of $0.003 \mu \mathrm{g} / \mathrm{kg}$ of weight): ${ }^{* *}-\mathrm{P}<0.01,{ }^{* * *}-\mathrm{P}<0.001$, difference between controls; $\mathrm{x} \pm \mathrm{SD}, \mathrm{n}=12$

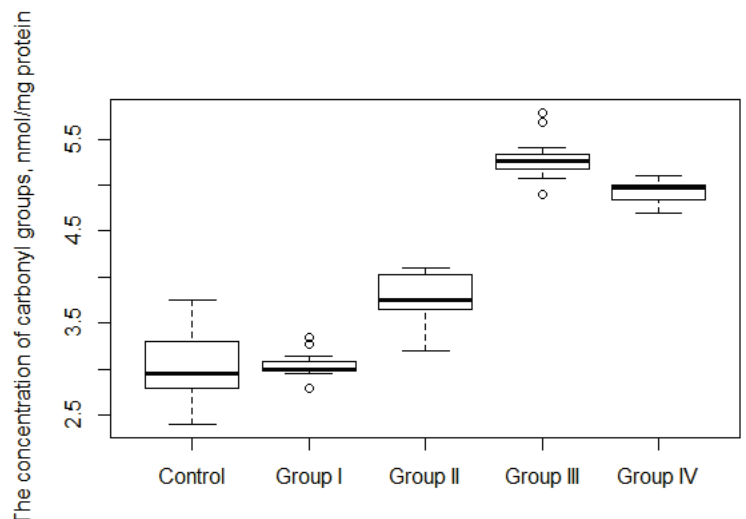

Fig. 2. The protein carbonylation level in the kidney homogenates of the first-generation rats fed with the traditional soybean, the transgenic soybean untreated and treated with the herbicide and the rats receiving the herbicide Roundup at the dose of $0.003 \mu \mathrm{g} / \mathrm{kg}$ of animal weight; $\square-$ median, the range of whiskers - not outliers,

$$
\circ \text { - outliers; } * \text { - extreme; } \mathrm{n}=12
$$

The box plots (Fig. 2) depict the normal distribution of carbonyl derivative concentrations in rat kidney homogenates. As shown in Figure 2, the highest concentration was observed for IV and V groups - 1.7 times higher than control. This may indicate an increase in active oxygen species in the kidney cells and an increase in their modifying effect on proteins.

The average medians of carbonyl derivatives in the kidney homogenates for the second and third generations of rats (Fig. 3, 4) were analyzed. It was established that the feeding of rats with the transgenic soybean treated with Roundup and watering with water containing the herbicide resulted in an increase of 1.7 times in the carbonyl derivatives content in the kidney homogenates of the second generation of rats, and of 1.7 (IV group) and 1.9 (V group) times for the third generation of rats. The feeding with the traditional soybean led to a slight increase in the carbonyl derivatives content in the rat kidney homogenates, and the feeding with the transgenic soybean not treated with the herbicide resulted in an increase of 1.4 times $\left(\mathrm{F}_{0}\right)$ and 1.3 times $\left(\mathrm{F}_{1}\right.$ and $\left.\mathrm{F}_{2}\right)$ in carbonyl derivatives content.

The damaging effect of free radicals on proteins is realized not only through interaction with $\mathrm{NH}_{2}^{-}$, but also with $\mathrm{SH}$-groups. Taking this into account, we explored the level of thiol-containing products in the kidney homogenates of three generations of rats fed with the traditional, transgenic soybeans treated and not treated with herbicide and receiving the herbicide with drinkable water. We noted a decrease in the content of thiol-containing products under these conditions, due to the oxidation of SH-groups by free radicals. The largest decreases were observed in IV and V groups in all generations of rats. (Fig. 5).

The average values of the thiol-containing products in the kidney homogenates of the first generation of rats (II and III groups) were analyzed. Thus, there was no change in the sulfhydryl groups' level in the kidneys of II group rats, while their level decreased by 1.2 times in the kidneys of III group rats, and it decreased by 1.3 times in IV and V group rats. Since $\mathrm{P}<0.05$, the difference between the group medians is statistically significant (Fig. 6).

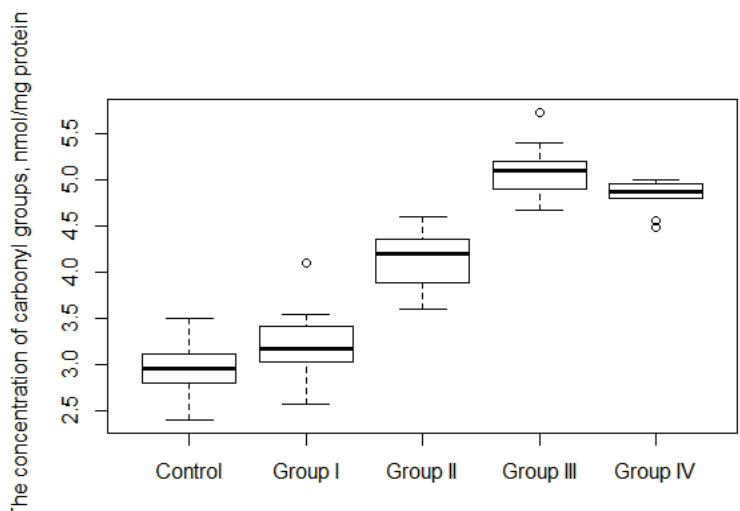

Fig. 3. The protein carbonylation level in the kidney homogenates of the second-generation rats fed with the traditional soybean, the transgenic soybean untreated and treated with the herbicide and the rats receiving the herbicide Roundup at the dose of $0.003 \mu \mathrm{g} / \mathrm{kg}$ of animal weight; $\square-$ median, the range of whiskers - not outliers, $\circ$ - outliers; ${ }^{*}$ - extreme; $\mathrm{n}=12$

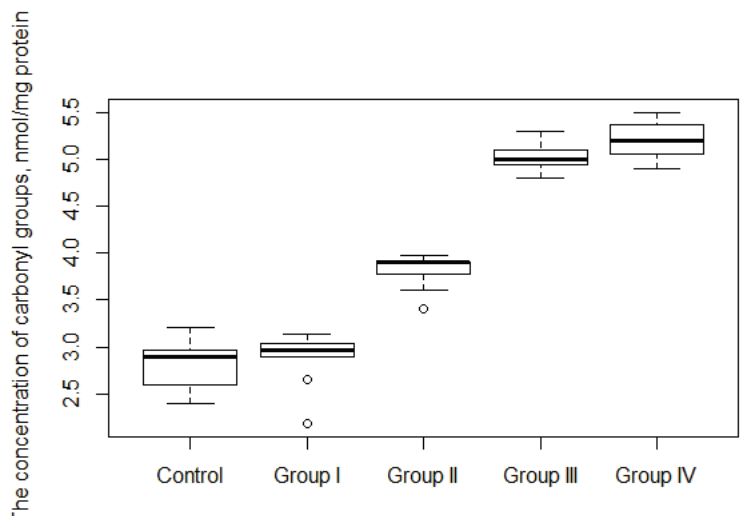

Fig. 4. The protein carbonylation level in the kidney homogenates of the third-generation rats fed with the traditional soybean, the transgenic soybean not treated and treated with the herbicide and the rats receiving the herbicide Roundup at the dose of $0.003 \mu \mathrm{g} / \mathrm{kg}$ of animal weight; $\square-$ median, the range of whiskers - not outliers, o- outliers; ${ }^{*}$ - extreme; $\mathrm{n}=12$

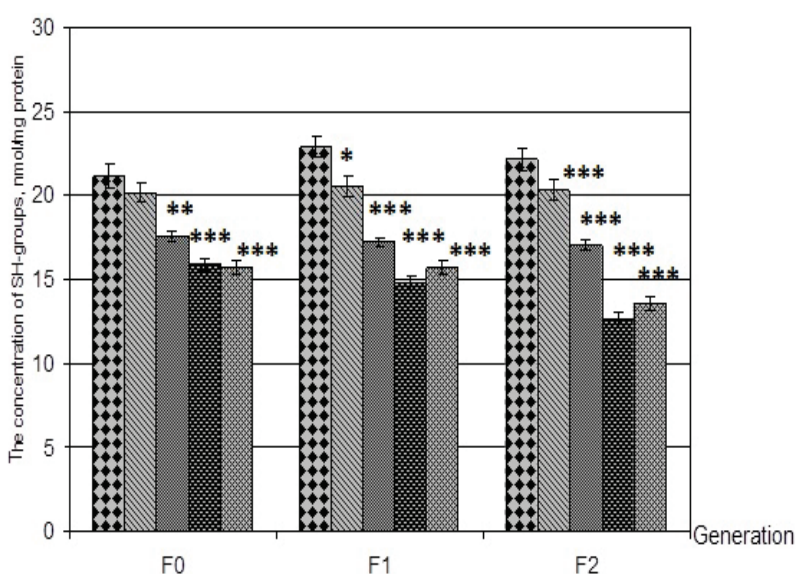

Fig. 5. The content of thiol-containing products in the kidney homogenates of the three rat generations consuming the traditional soybean, the transgenic soybean treated and not treated with the herbicide and the herbicide Roundup itself at the dose of $0.003 \mu \mathrm{g} / \mathrm{kg}$ of animal weight: ** $-\mathrm{P}<0.01, * * *-\mathrm{P}<0.001$, difference between controls; $\mathrm{x} \pm \mathrm{SD}, \mathrm{n}=12$ 


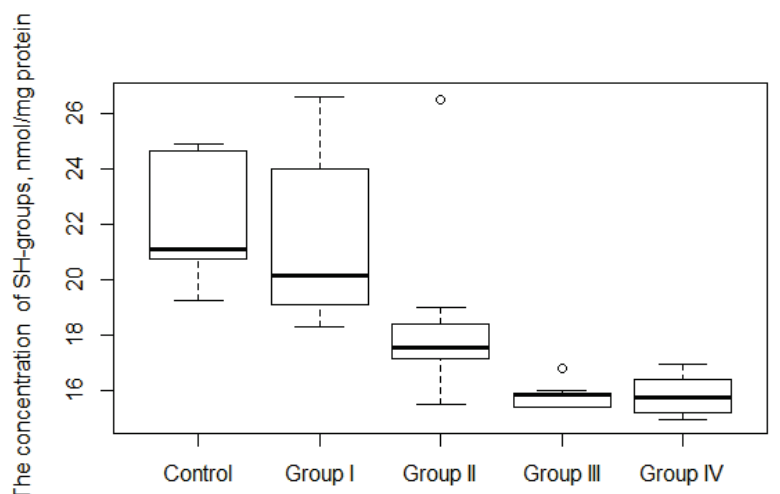

Fig. 6. The content of thiol-containing products in the kidney homogenates of the first generation of rats consuming the traditional soybean, the transgenic soybean treated and not treated with the herbicide and the herbicide Roundup itself at the dose of $0.003 \mu \mathrm{g} / \mathrm{kg}$ of animal weight; $\square-$ median, the range of whiskers - not outliers,

$$
\circ \text { - outliers; * - extreme; } \mathrm{n}=12
$$

The thiol-containing products content in the II group rats of the second and third generations was not changed, and in the III group rats it was decreased by 1.3 times in each rat generation in comparison with the intact group. At the same time, the significant reduction of thiol-containing products' content (decreased by 1.5 times) in the cells of IV and V group rats of the second generation was observed. In the third rat generation (IV and $\mathrm{V}$ groups), their level was reduced by 1.7 and 1.6 times respectively (Fig. 7, 8). SH-groups have antioxidant properties with high reactivity in oxidation-reduction reactions. Therefore oxidative stress occurring as the result of imbalance between free radical production and the antioxidant control mechanisms decreases their number.

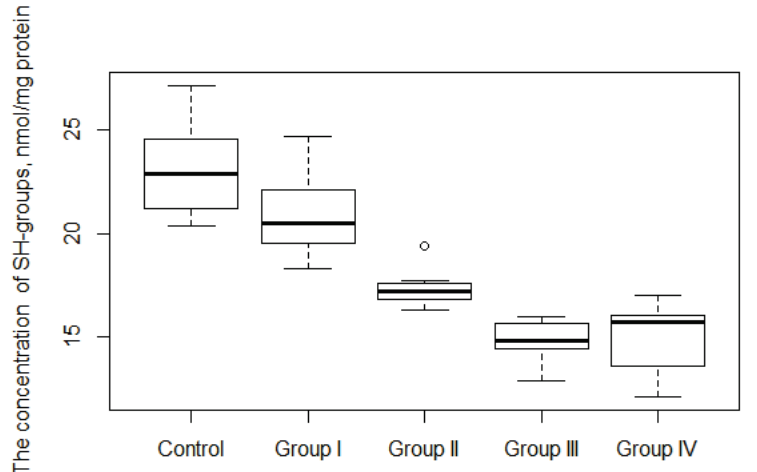

Fig. 7. The content of thiol-containing products in the kidney homogenates of the second generation of rats consuming the traditional soybean, the transgenic soybean treated and not treated with the herbicide and the herbicide Roundup itself at the dose of $0.003 \mu \mathrm{g} / \mathrm{kg}$ of animal weight; $\square-$ median, the range of whiskers - not outliers,

$$
\text { o- outliers; }{ }^{*} \text { - extreme; } \mathrm{n}=12
$$

An increase in protein oxidative modification in kidney cells can lead to their fragmentation or to formation of protein aggregates. The fragmentation of protein molecules can occur as a result of the direct action of active oxygen species or as a consequence of increasing their sensitivity to proteolysis. Therefore it is advisable to determine the activity of proteolytic enzymes in the kidney homogenates of the rats fed with the traditional soybean, genetically modified soybean treated and not treated with the herbicide, and the rats given water containing the herbicide.

The analysis of the research results showed that eating the transgenic soybeans treated with the herbicide and consuming the herbicide itself led to a decrease in the activity of proteolytic enzymes (alkaline and neutral) in the rat kidneys in comparison with the intact rats. (Fig. 9). The feeding of rats with the herbicide-treated transgenic soybeans and provided with water containing the herbicide led to an intensification of free radical processes, probably causing protein and enzyme oxidative modification. The proteolytic enzyme activity in the IV and V group rats decreased by 1.5 and 2.0 times respectively in the first generation (Fig. 10), by 1.9 and 2.3 times respectively in the second generation (Fig. 11), and by 2.2 and 2.4 times respectively in the third generation of rats (Fig. 12).

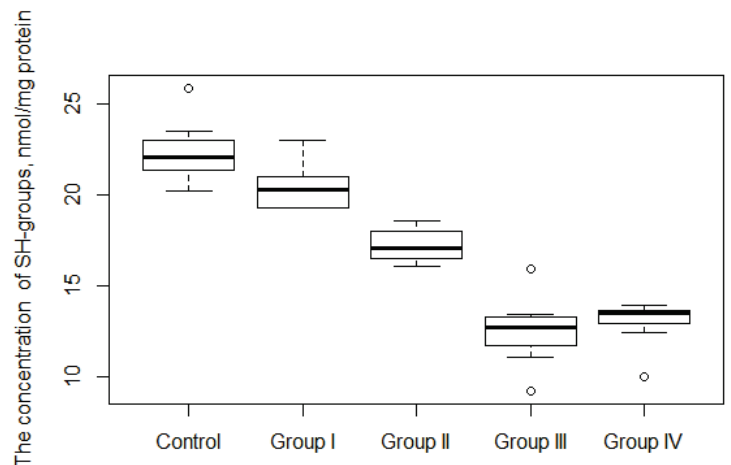

Fig. 8. The content of thiol-containing products in the kidney homogenates of the third generation of rats consuming the traditional soybean, the transgenic soybean treated and not treated with the herbicide and the herbicide Roundup itself at the dose of $0.003 \mu \mathrm{g} / \mathrm{kg}$ of animal weight; $\square$ - median, the range of whiskers - not outliers, o- outliers; * - extreme; $\mathrm{n}=12$

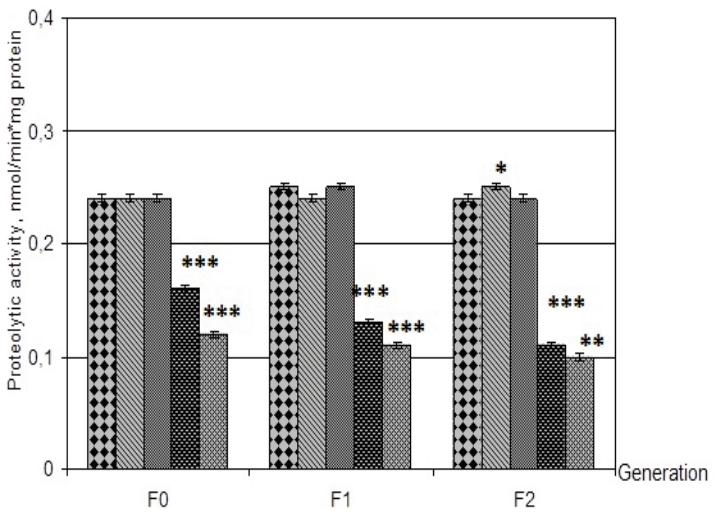

Fig. 9. The proteolytic enzymes' activity in the kidney homogenates of the three rat generations fed with the traditional soybean, the transgenic soybean treated and not treated with the herbicide and receiving the herbicide Roundup itself at the dose of $0.003 \mu \mathrm{g} / \mathrm{kg}$ of animal weight: ** $-\mathrm{P}<0.01,{ }^{* * *}-\mathrm{P}<0.001$ difference between controls $\mathrm{x} \pm \mathrm{SD}, \mathrm{n}=12$

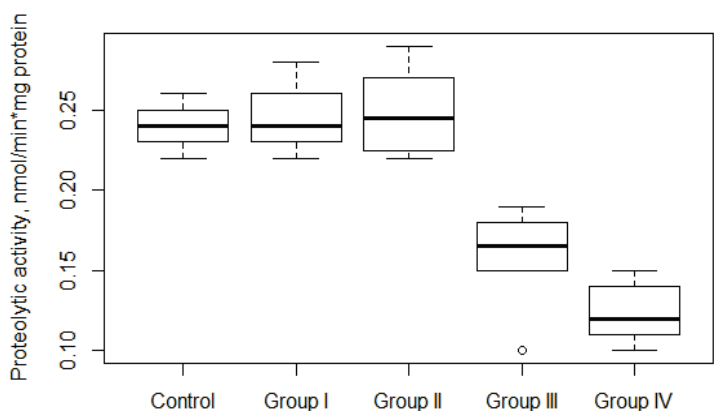

Fig. 10. The proteolytic enzymes' activity in the kidney homogenates of the first generation of rats fed with the traditional soybean, the transgenic soybean treated and not treated with the herbicide and receiving the herbicide Roundup itself at the dose of $0.003 \mu \mathrm{g} / \mathrm{kg}$ of animal weight; $\square-$ median, the range of whiskers - not outliers,

$$
\text { o- outliers; *- extreme; } \mathrm{n}=12
$$

Box plots (Fig. 10) depict the normal distribution of proteolytic enzymes' activity in the rats' kidney homogenates. The medians are close to the plot center for the I and III groups and a little shifted for the II group. The "whiskers" are symmetrical for the I group and slightly shifted for the II and III groups. There are not significant outliers in the results. Thus we can conclude that these plots do not have significant deviations from the standard, hence they show the normality of the data 
distribution. The medians are not close to the plot center for the IV and V experimental groups; the "whiskers" are asymmetrical (IV group), hence, this may indicate a deviation from the standard and, therefore, nonparametric results.

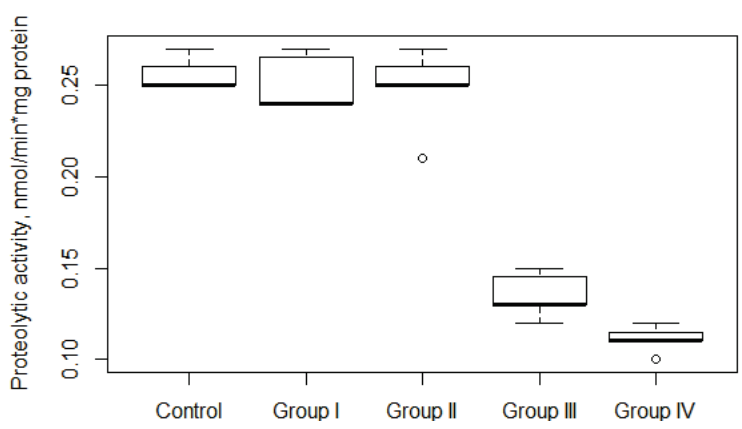

Fig. 11. The proteolytic enzymes' activity in the kidney homogenates of the second generation of rats fed with the traditional soybean, the transgenic soybean treated and not treated with the herbicide and receiving the herbicide Roundup itself at the dose of $0.003 \mu \mathrm{g} / \mathrm{kg}$ of animal weight; $\square-$ median, the range of whiskers - not outliers, o-outliers; $*$-extreme; $\mathrm{n}=12$

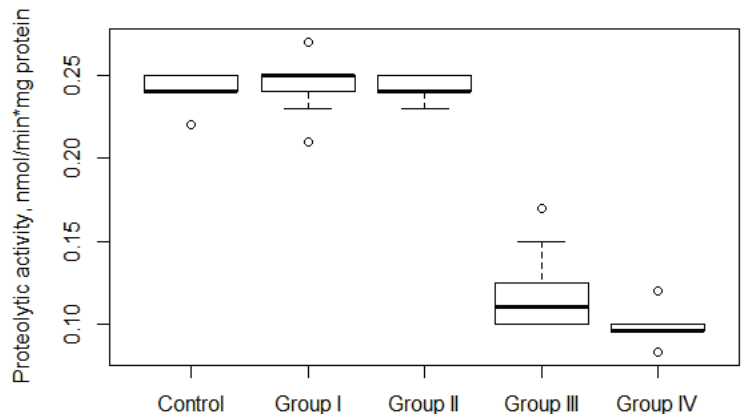

Fig. 12. The proteolytic enzymes' activity in the kidney homogenates of the third generation of rats fed with the traditional soybean, the transgenic soybean treated and not treated with the herbicide and receiving the herbicide Roundup itself at the dose of $0.003 \mu \mathrm{g} / \mathrm{kg}$ of animal weight; $\square-$ median, the range of whiskers - not outliers, $\circ$ - outliers; * - extreme; $\mathrm{n}=12$

Statistical processing of the data was performed according to nonparametric Kruskal-Wallis test, as an alternative to one-dimensional (intergroup) analysis of variance. It tested the null hypothesis that samples are taken from the same distribution or from distributions with the same medians: $\mathrm{H}_{0}$ : each group has the same distribution\} and $\mathrm{H}_{1}$ : :each group does not have the same distribution\}. The Kruskal-Wallis test answers the question of whether there is a difference between the group distributions (in particular, about existence of statistically significant difference in means), but does not indicate which groups are different.

The Conover-Iman test (Conover \& Iman, 1979; Conover, 1999) was used to compare stochastic domination and to determine the results of various pairwise comparisons after the Kruskal-Wallis test for stochastic domination among $\mathrm{n}$ groups (Kruskal \& Wallis, 1952). A pairwise comparison with the Conover-Iman test is valid if and only if the corresponding null hypothesis of Kruskal-Wallis is rejected and it is more powerful than Dunn's post-hoc test (1964). Like the rank test, the Conover-Iman test can be considered as the median difference test if the data can be deemed to be continuous (numerical) and the distributions are considered identical, with the exception of the location difference. Consequently, POM has both a negative and a positive effect, because it leads to the formation of inactive or low-activity enzymes, functionally defective proteins, but also POM is a stimulus to renewal of proteins. The oxidative modification of proteins, in addition, significantly increases their availability to the action of proteolytic enzymes. That is why the proteolytic enzymes play an important role in the degradation of oxidized proteins. Therefore, the determination of oxidatively modified proteins, the content of SH-groups and the content of proteolytic enzymes in the tissues of animals fed with GM foods can show the intensity of free radi- cal processes and the degree of protein oxidation. Consequently, the protein oxidative modification is a marker of the intensity of peroxide processes and a factor influencing the antioxidant system state.

\section{Discussion}

Active oxygen species are constantly being formed in aerobic organisms in response to endogenous and exogenous factors, although it was previously believed that their formation in the cell (oxidative burst) is a manifestation of the nonspecific immune defense against pathogens. Free radicals at physiological concentration are involved in a signal transduction in the cell and protect against microorganisms. There is a dynamic equilibrium between the content of prooxidants stimulating free radical oxidation of biopolymers and the antioxidant system activity in living systems at physiological norm. Various exogenous and endogenous factors stimulate the formation of reactive oxygen species and suppress antioxidant system activity leading to the activation of free radical oxidation processes. Human and animal organisms react to such influences and adapt to them. However, under various forms of stress, pathological conditions and the action of toxic substances, there is an excessive formation of free radicals leading to damage to cell structure, metabolic processes, and the initiation of protein, nucleic acid and lipid oxidation. (Netyukhilo \& Kharchenko, 2014). One of the main markers of protein oxidative modification is an increase in the number of carbonyl derivatives and a decrease in the content of free sulfhydryl groups (Fig. 5).

The feeding of animals with the transgenic soybean and the herbicide Roundup can cause damage in the structure of animal's internal organs (Dmukhalska, 2015; Gorbach, 2016), change in blood biochemical parameters, and can inhibit the antioxidant enzymes' activity (Saliha \& Snitinsky, 2010; Larsen et al., 2012; Zinoviev, 2014; Maximovsky et al., 2015), leading to imbalance of pro- and anti-oxidant equilibrium. The study of glyphosate, the main active ingredient of the herbicide Roundup, has shown that it negatively affects animal organisms. In particular, glyphosate can cause the inhibition of cytochrome $\mathrm{P}_{450}$ enzymes taking part in neutralization (detoxification) of harmful chemicals in mammal organisms. Consequently, glyphosate can cause the overload of the body with chemicals such as aluminum, lead, arsenic, or any other toxic substances (Dmukhalska \& Honskyi, 2016). The studies carried out by French scientists showed the toxic effect mechanisms of four different compositions of the herbicide Roundup on the human umbilical cord blood cells. Those researches demonstrated that even the minimum concentration of the herbicide Roundup results in damage to cell membranes and DNA. In addition, it turned out that Roundup prevents cellular respiration. Interruption of oxidation in the respiratory chain may lead to free radicals' formation causing the oxidation of biomolecules: proteins, lipids and carbohydrates (Benachour, 2009). Scientists claim the excipients of the herbicide Roundup can reinforce the action of the main substance (glyphosate). Also, it remains an open question whether the herbicide Roundup can actually accumulate in the seeds of soybean and other crops (Saz et al., 2007; Bohn et al., 2014). The study of the determination of glyphosate in seeds revealed that it was contained in both seeds of transgenic cereal crops and transgenic leguminous plants $(0.2-4.8 \mu \mathrm{g} / \mathrm{kg})$, although during industrial processing the glyphosate residues' content may be reduced (from 1.6 to $0.16 \mu \mathrm{g} / \mathrm{kg}$ ). In reference to other studies, the glyphosate residues' content in flour can reach 10 $20 \%$ of its content in wheat and they do not break down even after heat treatment (Kuznetsova et al., 2010).

The results of our experimental studies revealed the negative influence of feeding with genetically modified soybean treated with the herbicide Roundup and consumption of the herbicide with drinking water in a dose of $0.003 \mu \mathrm{g} / \mathrm{kg}$ of weight on rat kidney cells. The biochemical studies showed that there was an increase in the level of carbonyl derivatives in the liver homogenates of IV and V group rats of the first generation, and their level almost doubled in the liver homogenates of the same groups of rats of the second and third generations, perhaps indicating initiation of free radical processes and formation of active oxygen species. Reduced content of thiol-containing products and decreased proteolytic activity of enzymes in kidney homogenates of IV and $\mathrm{V}$ rat groups of all three generations were also observed. The lowest contents of thiol-con- 
taining products (decreased by 1.6 and 1.7 times) were found in kidney homogenates of IV and $\mathrm{V}$ rat groups of the third generation respectively. SH-groups have antioxidant properties, high reactivity in oxidationreduction reactions, and therefore their number decreases with oxidative stress occurring as the result of imbalance between free radical production and the antioxidant control mechanisms.

The decrease in proteolytic enzymes' activity in the kidneys may be caused by oxidative modification of proteases due to action of free radicals. Consequently long-term feeding with transgenic soybeans and consumption of herbicides result in enhancement of free radical processes, most observed in the third generation of rats. Probably that is why the proteolytic enzymes' activity was reduced by 2.2 and 2.4 times in the IV and V group respectively.

Thus, the increasing level of carbonyl derivatives as well as the reduction in the content of thiol-containing products and the decreasing of enzymes' proteolytic activity in the kidney homogenates of IV group rats are due to the accumulation of the herbicide Roundup in the genetically modified soybean seeds, which can remain even after heat treatment. The same situation was observed for the rats of $\mathrm{V}$ group. As the difference between IV and V groups was not statistically significant, this indicates precisely the herbicide's toxic effect and the initiation of free radical processes in the rat kidney cells.

\section{Conclusions}

One of the reasons for the increase in the carbonyl derivatives' concentration in the kidney homogenates of the rats fed with the genetically modified soybean treated with the herbicide Roundup and provided with water containing the herbicide may be the toxic effects of the herbicide itself or its residues in soybean seeds. The toxic effects of the herbicide can lead to the inhibition of antioxidant system activity, especially first order enzymes, which are capable of neutralizing the active oxygen species, directly causing peroxidation of proteins. Besides, in the conditions of the long-term consumption of the transgenic soybeans treated with the herbicide and drinking water containing the herbicide, processses of POM with the accumulation of the formed products are intensified due to a decrease in the activity of proteases involved in the destruction of modified proteins. Thus, the content of neutral-type aldehyde- and ketone derivatives of proteins (POM370) in the rat kidney homogenates of third-generation rats increased by 1.7 and 1.9 times compared with the intact rats. In IV and V groups, the content of thiol containing products, on the contrary, decreased, which may indicate the effect of free radicals on proteins. The content of thiol-containing products decreased for IV and V group rats, indicating the influence of free radicals' on proteins. Hence, the obtained results showed that feeding with the genetically modified soybean treated with the herbicide and consumption of the herbicide Roundup with drinkable water lead to an increase in free radical processes in rat kidney cells and an imbalance of the pro- and antioxidant system for three generations of the rats.

\section{References}

Anne, C., Cornille, F., \& Lenoir, C. (2001). High-throughput fluorogenic assay for determination of botulinum type B neurotoxin protease. Analytical Biochemistry, 291(2), 253-261.

Benachour, N. (2009). Glyphosate formulations induce apoptosis and necrosis in human umbilical, embryonic, and placental cells. Chemical Research in Toxicology, 22(1), 97-105.

Bilan, M. V., Lieshchova, M. A., Tishkina, N. M., \& Brygadyrenko, V. V. (2019). Combined effect of glyphosate, saccharin and sodium benzoate on the gut microbiota of rats. Regulatory Mechanisms in Biosystems, 10(2), 228-232.

Bohn, T., Cuhra, M., Traavik, T., Sanden, M., Fagan, J., \& Primicerio, R. (2014). Compositional differences in soybeans on the market: Glyphosate accumulates in Roundup ready GM soybeans. Food Chemistry, 153(15), 207-215.

Dmukhalska, Y. B. (2015). Strukturni zminy vnutrishnikh orhaniv u molodykh shchuriv, urazheni solyamy vazhkykh metaliv i fosfororhanichnymy pestytsydamy [The structural changes of internal organs in young rats affected by the heavy metal salts and phosphororganic pesticides]. Medical and Clinical Chemistry, 17(2), 47-51 (in Ukrainian).
Dmukhalska, Y. B., \& Honskyi, Y. I. (2016). Effect of peptides on antioxidant system enzymes in rats with heavy metals, phosphoorganic pesticides intoxication. Medical and Clinical Chemistry, 18(2), 22-27.

Dmukhalska, Y. B., \& Honskyi, Y. I. (2016). Vplyv vazhkykh metaliv, fosfororhanichnykh pestytsydiv ta peptydiv na aktyvnist' fermentiv hlutationovoyi systemy [The influence of heavy metals, organophosphorus pesticides and peptides on the activity of enzymes of the glutathione system]. Medical and Clinical Chemistry, 18(1), 70-74 (in Ukrainian).

Dubinina, E. E., Burmistrov, S. O., Hodov, D. A., \& Porotov, I. G. (1995). Okyslyuval'na modyfikatsiya bilka syrovatky lyudyny, sposib yoho vyznachennya [Oxidative modification of human serum protein, method of its determination]. Questions of Medical Chemistry, 41(1), 24-26 (in Ukrainian).

Gorbach, T. V., Gubina-Vakulik, G. I., \& Denisenko, S. A. (2016). Vplyv henetychno modyfikovanoyi soyi $\mathrm{v}$ ratsioni bilykh shchuriv na metabolizm $\mathrm{i}$ histolohiyu pechinky i nyrok u bat'kiv i nashchadkiv [Influence of genetically modified soya in the diet of white rats on the metabolism and histology of the liver and kidneys from parents and descendants]. Problems of Aging and Longevity, 25(10), 80-86 (in Ukrainian).

Ketsa, O. V., Shmarakov, I. O., \& Marchenko, M. M. (2016). Perekysne okyslennya lipidiv u mitokhondrial'niy fraktsiyi sertsya shchuriv, piddanykh riznym dobavkam polinenasychenykh zhymykh kyslot [Lipid peroxidation in cardiac mitochondrial fraction of rats exposed to different supplementation with polyunsaturated fatty acids]. Biomeditsinskaya Khimiya, 62, 50-55 (in Ukrainian).

Kulik, M. F., Korniychuk, O. V., Bugayov, V. D., \& Obertyukh, Y. V. (2013). Inhibuvannya rostu zarodkiv zerna pshenytsi, trytykale i zhyta pid vplyvom vodnoyi ekstraktsiyi kruhloho stabil'noho HM-soyi porivnyano z ne-HM soyeyu [Inhibition of growth in the germ of wheat grain, triticale and rye under the influence of water extraction of round-stable GM-soya compared to non-GM soybean]. Bulletin of Agrarian Science, 6, 21-24 (in Ukrainian).

Kulik, Y. M., Rauzkiene, V. T, Obertyuk, Y. V., Khimich, O. V., \& Rimsha, O. I. (2015). Identyfikatsiya nevstanovlenoho faktora transhenetychnoyi soyi u vnutrishnikh orhanakh shchuriv z yoho tryvalym kharchuvannyam [Identification of the unidentified factor of transgenetic soy in the internal organs of rats which were given this diet over a prolonged period]. Bulletin of the Vinnytsia National Medical University University, 19(2), 144-150 (in Ukrainian).

Kulik, Y. M., Rauzkiene, V. T., Obertyuk, Y. V., \& Khimich, O. V. (2015). Nayavnist' u nashchadkiv shchuriv nevstanovlenoho faktora transhennoyi soyi pid chas yiyi hodivli protyahom dekil'kokh pokolin' [Presence in the offspring of rats of the unidentified factor of transgenic soybeans during its feeding for several generations]. Bulletin of Biological and Medical Problems, 124, 105-109 (in Ukrainian).

Kuznetsova, E. M., \& Chmil, V. D. (2010). Hlifosat: Povedinka navkolyshn'oho seredovyshcha i rivni zalyshkiv [Glyphosat: Environmental behavior and residue levels modern]. Problems of Toxicology, 1, 87-95 (in Ukrainian).

Larsen, K., Najle, R., Lifschitz, A., \& Virkel, G. (2012). Effects of sub-lethal exposure of rats to the herbicide glyphosate in drinkable water: Glutathione transferase enzyme activities, levels of reduced glutathione and lipid peroxidation in liver, kidneys and small intestine. Environmental Toxicology and Pharmacology, 34, 811-818.

Lieshchova, M. A., Tishkina, N. M., Bohomaz, A. A., Gavrilin, P. M., \& Brygadyrenko, V. V. (2018). Combined effect of glyphosphate, saccharin and sodium benzoate on rats. Regulatory Mechanisms in Biosystems, 9(4), 591-597.

Manishchenko, Y. O., Orlova, O. A., \& Scale, L. V. (2010). Okyslyuval'na modyfikatsiya bilkiv u khvorykh z komorbidnoyu patolohiyeyu [Oxidation modification of proteins in patients with comorbid pathology]. Ukrainian Journal of Clinics and Laboratory Medicine, 5(1), 126-129 (in Ukrainian).

Marchenko, M. M., \& Ketsa, O. V. (2012). Funktsional'naya aktivnost' NADHzavisimoy reduktaznoy sistemy v pecheni i mikrosomal'noy fraktsii kartsinomy Gerena u krys, podvergnutykh predvaritel'nomu oblucheniyu [Functional activity of the NADH-dependent reductase system in liver and Guerin's carcinoma microsomal fraction in rats exposed to preliminary irradiation]. Biochemistry (Moscow) Supplement Series B: Biomedical Chemistry, 6(4), 321-327 (in Russian).

Maximovsky, S. Y., Kudrin, B. I., \& Plotnikova, O. M. (2015). Izmeneniya morfologicheskikh i biokhimicheskikh pokazateley krovi melkikh mlekopitayushchikh pod vliyaniyem glifosata [Changes in the morphological and biochemical parameters of blood of small mammals under the influence of glyphosate]. News of the Orenburg State Agrarian University, 54, 93-95 (in Russian).

Mesnage, R., Renney, G., \& Séralini, G.-E. (2017). Multiomics reveal non-alcoholic fatty liver disease in rats following chronic exposure to an ultra-low dose of Roundup herbicide. Scientific Reports, 7, 1-15.

Murphy, M. E., \& Kehrer, J. P. (1989). Oxidation of tissue thid groups and content of protein carbonyl groups in chickens with Inherited muscular dystrophy. Biochemical Journal, 260(2), 359-364.

Myers, J. P., Michael, N. A., \& Blumberg, B. (2016). Concerns over use of glyphosate-based herbicides and risks associated with exposures. Environmental Health, 2016, 1-13. 
Natarajan, S. (2007). Proteomic and genetic analysis of glycinin subunits of sixteen soybean genotypes. Plant Physiology and Biochemistry, 45, 436- 444.

Netyukhilo, L. G., \& Kharchenko, S. V. (2014). Aktyvni formy kysnyu [Active forms of oxygen]. Young Scientist, 9(12), 131-135 (in Ukrainian)

Richard, S., Moslemi, S., Sipahutar, H., Benachour, N., \& Seralini, G. E. (2005). Differential effects of glyphosate and roundup on human placental cells and aromatase. Environmental Health Perspectives, 113, 716-720.

Saliha, N. O., \& Snitinsky, V. V. (2010). Henetychno modyfikovani roslyny ta yikh vplyv na orhanizm tvaryn [Genetically modified plants and their influence on the organism of animals]. The Animals Biology, 12(2), 61-74 (in Ukrainian).

Saz, J. M., \& Marina, M. L. (2007). High performance liquid chromatography and capillary electrophoresis in the analysis of soybean proteins and peptides in foodstuffs. Journal of Separation Science, 30(4), 431-451.
Woodmaska, I. V., Paranyak, R. P., Yanovich, D. O., Semenovich, V. K., \& Golubets, R. A. (2007). Otsinka yakosti ta bezpeky henetychno modyfikovanykh orhanizmiv [Assessment of the quality and safety of genetically modified organisms]. The Animals Biology, 9, 23-29 (in Ukrainian).

Zagrebelny, V. O., Gaydy, O. S., \& Usachenko, N. V. (2014). Analiz rezul'tativ vyznachennya HMO v syrovyni roslynnoho pokhodzhennya v 2013 rotsi [Analysis of results of determination of GMOs in raw materials of vegetable origin in 2013]. Veterinary Medicine, 98, 158-161 (in Ukrainian).

Zinoviev, S. G. (2014). Deyaki biokhimichni pokaznyky krovi svyney z vykorystannyam HM-soyi v yikh ratsionakh [Some biochemical parameters of blood of pigs using GM-soya in their diets]. The Animal Biology, 16(1), 76-82 (in Ukrainian). 